\title{
Total Ammonia Nitrogen (TAN) Removal Efficiency in Recirculating Aquaculture Systems by using Sponge-Bed Trickling Filter
}

\author{
Yenny Silvia and Setyo Sarwanto Moersidik \\ Department of Civil Engineering, Universitas Indonesia, Depok, Jawa Barat, Indonesia \\ ssarwanto@eng.ui.ac.id, +62217270029
}

\begin{abstract}
Sponge-bed trickling filter is a recirculating aquaculture systems technology that capable of managing Total Ammonia Nitrogen (TAN) in water until it reaches its safe threshold for fish. The study was conducted on a laboratory scale using a $13 \times 13 \times 28 \mathrm{~cm}^{3}$ sponge media trickling filter. The trickling filter height and flowrate were $40 \mathrm{~cm}$ and $3 \mathrm{~L} / \mathrm{min}$, respectively. The influent used was synthetic wastewater with water quality similar to Osphronemus goramy Lac. Aquaculture with an average weight of $0.013 \mathrm{~g}$ derived from the addition of ammonia solution with load variations of $0.4,0.6$ and $0.8 \mathrm{mg}$ TAN/L. During seven repetitions of observations at each load, the results showed that the loading of $0.8 \mathrm{mg} \mathrm{TAN} / \mathrm{L}$ resulted in a relatively high removal efficiency and a stable Volumetric TAN Removal(VTR) of $96.41 \pm 0.880 \%$ and $0.0157 \pm 0.00105 \mathrm{~g} / \mathrm{m}^{3}$ day. The nitrification reaction took place on first order kinetics with the highest rate of removal occurring at $0.8 \mathrm{mg} \mathrm{TAN} / \mathrm{L}$ load of $0.67 \mathrm{~g} / \mathrm{m}^{2}$ day. First-order kinetics is not an optimum condition for sponge-bed trickling filter operations but the $0.8 \mathrm{mg} \mathrm{TAN} / \mathrm{L}$ load selection minimizes the impact of first-order kinetics as it results in relatively stable percentages and VTRs.
\end{abstract}

Key words: Sponge-bed trickling filter, Total Ammonia Nitrogen (TAN), first order kinetics, Recirculating Aquaculture Systems (RAS), Volumetric TAN Removal (VTR), percentages

\section{INTRODUCTION}

Intensive aquaculture systems can boost fish production through improved seed, artificial high protein feed and high stocking density in a limited area. However, intensive systems cause water quality problems that high levels of ammonia-nitrogen will be secreted up to $120 \mathrm{~kg} / \mathrm{m}^{3}$. Ammonia which is a product of protein catabolism in aquatic organisms has two forms in water, toxic and unionized ammonia $\left(\mathrm{NH}_{3}\right)$ and ionized ammonia $\left(\mathrm{NH}_{4}{ }^{+}\right)$. The sum of both forms is referred to as Total Ammonia-Nitrogen (TAN).

When the ammonia levels exceed the limit, the internal physiological $\mathrm{pH}$ will increase and cause metabolic imbalances (Suantika et al., 2016). It encourages farmers to manage water. Quality, so that, the diseases could be avoided. To reduce these impacts, Recirculating Aquaculture Systems (RAS) can be used to manage water quality and quantity of ammonia which is produced on fisheries. TAN removal using RAS is effectively implemented using fixed biofilm reactor for wastewater characteristics of fisheries. The trickling filter is one of the reactor processes ammonia by using fixed media where water flowed in the form of droplets through the media along the trickling filter reactor (Eding et al., 2006), thus, this research needs to be conducted to determine how the performance of RAS is able to treat wastewater produced from freshwater aquaculture.

Based on the facts above, the aims of this study are to investigate the effect of load variations in the operation of sponge-bed trickling filter and to investigate the kinetics of nitrification in sponge-bed trickling filter performance.

\section{MATERIALS AND METHODS}

Simulation of wastewater samples: The raw water used was groundwater in Faculty of Engineering, Universitas Indonesia, Depok whose quality was adjusted, so, appropriate for nitrification and cultivation of fish with values as follows $\mathrm{DO} 4-7.5 \mathrm{mg} / \mathrm{L} ; \mathrm{pH} 6.5-8.5$ a temperature of $28.3-32^{\circ} \mathrm{C}$ and alkalinity of $195 \mathrm{mg} / \mathrm{L} \mathrm{CaCO}_{3}$.

Based on Sarah et al. synthetic wastewater was assumed to come from aquaculture of Osphronemus goramy Lac. with $5,7.5$ and 10 fish/L stocking density and the frequency of the load was assumed to come from the feed that was given once a day. The research was carried

Corresponding Author: Setyo Sarwanto Moersidik, Department of Civil Engineering, Universitas Indonesia, Depok, Jawa Barat, Indonesia, ssarwanto@eng.ui.ac.id, +62217270029 
out by using a water volume of $72 \mathrm{~L}$ on the pool dimensions of $60 \times 40 \times 40 \mathrm{~cm}$. Total TAN produced for each load was assumed as $0.4,0.6$ and $0.8 \mathrm{mg} / \mathrm{L}$.

Sponge-bed trickling filter design: The design process of sponge-bed trickling filter used equations on a spreadsheet by Losordo and Hobbs (2000). The sponge-bed trickling filter was made of glass with a square shape whose dimensions $13 \times 13 \times 38 \mathrm{~cm}^{3}$. The thickness of the media was $28 \mathrm{~cm}$ and composed of layered sponge material. The wastewater was trickled from the top to the bottom of the biofilter (downflow) at $3 \mathrm{~L} / \mathrm{min}$.

Seeding and feeding process: The bacteria used was a liquid consortium of bacterial inoculation containing Nitrosomonas and Nitrobacter. Bacteria were inoculated in synthetic water and sponge media. TAN as the food supply for bacteria during seeding process was derived from the content of that liquid which increased the concentration of TAN until $5.68 \mathrm{mg}$ TAN/L in water, TAN addition was also done at loads of 0.8 and $0.4 \mathrm{mg}$ TAN/L day. Seeding process lasted for 19 days to reach steady-state conditions.

Feeding process took place after the concentration of nitrite produced in the seeding process was at a stable level after reached peak concentration and removal efficiency exceeded $80 \%$. Feeding process was using the same operating system as the seeding process. Feeding process took place with variations of load testing that began with testing the load of $0.4 \mathrm{mg} \mathrm{TAN} / \mathrm{L}$ days followed by the load of 0.6 and $0.8 \mathrm{mg}$ TAN/L day. The test started with the lowest load, so, the process occurred gradually to avoid shock loading. The addition of TAN load came from the addition of $25 \%$ ammonia solution with the volume adjusted with water volume and the load variations on the assumption that the volume of water did not contain TAN. Calculation of the ammonia solution was based on the theory of concentration mixing with $25 \%$ ammonia solution concentration of $130909 \mathrm{mg} / \mathrm{L}$, so that, the volume of ammonia solution was added to the load of $0.4,0.6$ and $0.8 \mathrm{mg}$ TAN/L day were 220,440 and $660 \mathrm{~mL} /$ day, respectively.

The parameters evaluated were TAN removal efficiency and Volumetric TAN Removal (VTR) value based on the results of the operation of the sponge-bed trickling filter for $24 \mathrm{~h}$. The test was conducted in seven repetitions of observation for each load variations tested in which each repetition was done for $24 \mathrm{~h}$, so, we got seven data of TAN removal efficiency and VTR value of each load.

Testing parameters: The concentration of TAN, nitrite and nitrate in water was measured by using a spectrophotometric method. $\mathrm{pH}$ was measured by using a $\mathrm{pH} \mathrm{m}$. Temperature measurement was done using a thermometer with probe. Titrimetric alkalinity was measured by using a method based on APHA method 2320.B. Dissolved oxygen was measured by using a DO meter by USEPA 40 CFR 136.3 .

Nitrification kinetics test: TAN will be degraded within $6 \mathrm{~h}$, so that, the kinetics testing conducted for $6 \mathrm{~h}$ with a time of measurement as follows (Ahnen et al., 2015) the first $30 \mathrm{~min}$; a span of $5 \mathrm{~min}, 30 \mathrm{~min}$ later; a span of 15,60 min later; a span of $30 \mathrm{~min}$ and last min 240 a span of $1 \mathrm{~h} 60 \mathrm{~min}$.

Data analysis and statistics: Sponge-bed trickling filter performance in designated TAN concentrations was analyzed quantitatively based on the TAN removal efficiency and VTR value associated descriptive analysis of the factors that influenced the process:

$$
\begin{gathered}
\text { Removal efficiency }=\frac{\text { TAN }_{\text {influent }} \text { TAN }_{\text {efficient }}}{\text { TAN }_{\text {influent }}} \\
\text { VTR }=\left(\text { TAN }_{1}-\text { TAN }_{E}\right) \frac{Q_{r}}{V_{b}}
\end{gathered}
$$

VTR value was the concentration of TAN removed per media filter volume in a day $\left(\mathrm{g} / \mathrm{m}^{3}\right.$ day $)$. VTR value could be the fundamental parameter for evaluating and comparing the performance of biofilter (Malone and Beecher, 2000).

Determination of kinetics that occurred in the sponge-bed trickling filter was executed by creating the graph plots the concentration of TAN (mg TAN/L) as the $\mathrm{Y}$-axis and the oxidation time as the $\mathrm{X}$-axis. The graphs were created using Microsoft Excel 2016 to decide which order of the reaction occurred. The statistical test was performed by ANOVA and box plot chart were also created using SPSS for VTR value and removal efficiency to see the spread of the data. The results of the analysis used to determine the most optimum load on TAN removal process.

\section{RESULTS AND DISCUSSION}

Seeding process: TAN removal lasted for 8 days with a maximum percentage of $69.4 \%$. Seeding process was continued until the second phase due to the removal efficiency on the first stage had not reached $80 \%$. In the second phase, the TAN removal efficiencies were around the percentage of $95-98 \%$. The second phase was 
Table 1: Average VTR and removal efficiency including the standard deviation for each load

\begin{tabular}{lcc}
\hline Load (mg TAN/L day) & $\begin{array}{c}\text { Average VTR } \\
\left(\mathrm{g} / \mathrm{m}^{3} \text { day }\right)\end{array}$ & $\begin{array}{c}\text { Average removal } \\
\text { efficiency }(\%)\end{array}$ \\
\hline 0.4 & $0.0077 \pm 0.00060$ & $90.66 \pm 7.955$ \\
0.6 & $0.0124 \pm 0.00095$ & $97.30 \pm 3.260$ \\
0.8 & $0.0157 \pm 0.00104$ & $96.41 \pm 0,880$ \\
\hline
\end{tabular}

conducted by adding a load of $\pm 0.8 \mathrm{mg} / \mathrm{L}$ day three times for 6 days of observation. In the third phase, the TAN load used was only $0.4 \mathrm{mg} / \mathrm{L}$ day. Seeding process was completed on the 19th day.

Seeding process was considered complete when the growth of nitrifying bacteria had been perfect and the removal efficiency of ammonia had reached a stable condition (Harwanto et al., 2011).

In the third phase, the influent of TAN used was only $0.4 \mathrm{mg} / \mathrm{L}$ day. This step was conducted because the nitrite concentration had not been stable yet. Seeding process was considered complete when the concentration of nitrite had been in stable condition or at low concentrations because it indicated that the Nitrobacter which was in charge to transform nitrite had been fully formed and grown, suitable to process the TAN load that had been set (Masser et al., 1992). The seeding process was completed on the 19th day where concentrations of nitrite were already likely to be stable at $3 \mathrm{mg} / \mathrm{L}$.

Feeding process: Overall, the removal efficiencies were in the range of $80-100 \%$. At a load of $0.4 \mathrm{mg} \mathrm{TAN} / \mathrm{L}$ day, the removal efficiencies were more fairly volatile. The removal efficiencies which tended to be more stable were at a load of $0.8 \mathrm{mg}$ TAN/L with a range of $94.37-97.65 \%$. The removal efficiencies that were likely to be stable on every load variation indicated that the rate of TAN removal on each load was getting bigger, so that, the greater the amount of TAN influent, the greater the VTR value Table 1.

Fluctuations of the removal efficiency at the load of $0.4 \mathrm{mg} \mathrm{TAN} / \mathrm{L}$ day were influenced by the condition adjustment from the seeding process to the feeding process where there were the differences in the loads given. A stable condition that occurred in the load of $0.8 \mathrm{mg} \mathrm{TAN} / \mathrm{L}$ day was influenced after the readjustment of alkalinity value up to $195 \mathrm{mg} / \mathrm{L} \mathrm{CaCO}_{3}$. This was conducted because the alkalinity before starting the process at a load of $0.8 \mathrm{mg} \mathrm{TAN} / \mathrm{L}$ day decreased to $2 \mathrm{mg} / \mathrm{L} \mathrm{CaCO}_{3}$, so that, the removal efficiency also decreased significantly by $70 \%$.

The removal efficiencies of sponge-bed trickling filter, compared to trickling filter by using LECA media by Bagaswari et al. were relatively more stable in removing TAN. Although, LECA produced higher removal efficiency for 0.6 and $0.8 \mathrm{mg} / \mathrm{L}$ day loading which
Table 2: Trendline equation and $\mathrm{R}^{2}$ of each load. The higher $\mathrm{R}^{2}$ numbers show that the equations would likely to yield more precise results as the reality

\begin{tabular}{lcl}
\hline Load variation (mg TAN/L) & $\mathrm{R}^{2}$ & Equations \\
\hline 0.4 & 0.8506 & $\mathrm{Y}=0.3228 \mathrm{e}^{-0.013 x}$ \\
0.6 & 0.9802 & $\mathrm{Y}=0.475 \mathrm{e}^{-0.01 x}$ \\
0.8 & 0.9452 & $\mathrm{Y}=0.6392 \mathrm{e}^{-0.01 x}$ \\
\hline
\end{tabular}

were 98 and $95.2 \%$, however, their standard deviations were 1.7 and $3.8 \%$, respectively while the in the sponge-bed, the deviation only 3.26 and $0.88 \%$ for loading 0.6 and $0.8 \mathrm{mg} / \mathrm{L}$ day, respectively.

Nitrification kinetics: Observations made during the three days beginning with the testing load of $0.8,0.6$ and $0.4 \mathrm{mg} \mathrm{TAN} / \mathrm{L}$, respectively and the initial concentration when adding ammonia solution at a load of $0.8,0.6$ and $0.4 \mathrm{TAN} \mathrm{mg} / \mathrm{L}$, respectively, $0.85,0.61$ and 0.44 whereas concentrations at minute 0 , respectively, 0.64 , 0.44 and $0.30 \mathrm{mg} \mathrm{TAN} / \mathrm{L}$. TAN concentration in the test with a load of $0.4 \mathrm{mg} \mathrm{TAN} / \mathrm{L}$ run at $240 \mathrm{~min}$ or $4 \mathrm{~h}$, this caused the data processing was only carried out up to 180 min or h to 3 wherein the concentration of TAN at that time was on TAN $0.1 \mathrm{mg} / \mathrm{L}$.

Based on Fig. 1 and Table 2, the chart is on the negative exponential trend which indicates that the reaction kinetics took place on first-order. This indicates that not all of TAN concentration produced could be processed, so that, there was TAN left on the system. This could lead to the accumulation of TAN when feeding process continued at a constant load and time. In the commercial cultivation, farmers must operate biofilter at suitable steady-state conditions, so that, the rate of nitrification or the TAN removal rate are fixed and consistent (Lyssenko and Wheaton, 2006).

Nitrite and nitrate production: During all of the feeding processes from the load of $0.4,0.6$ and $0.8 \mathrm{mg}$ TAN/L day, nitrites were stable at concentrations below $5 \mathrm{mg} / \mathrm{L}$ whereas nitrates continue to accumulate up to $27 \mathrm{mg} / \mathrm{L}$. Nitrates and nitrites are a by-product derived from the decomposition by Nitrosomonas and Nitrobacter.

Nitrates tended to increase or be accumulated during the period of observation, this was because of the absence of a process for denitrification process where conditions require bacteria living in anoxic conditions whereas anoxic conditions were avoided in this process to prevent inhibition toward ammonia decomposition.

Determining optimum load: Removal efficiency and value VTR with the largest value were taken as considerations for the most optimum feeding load. The value of the kinetics constants and rate were also taken into account to decide which load was the most suitable for the system. 


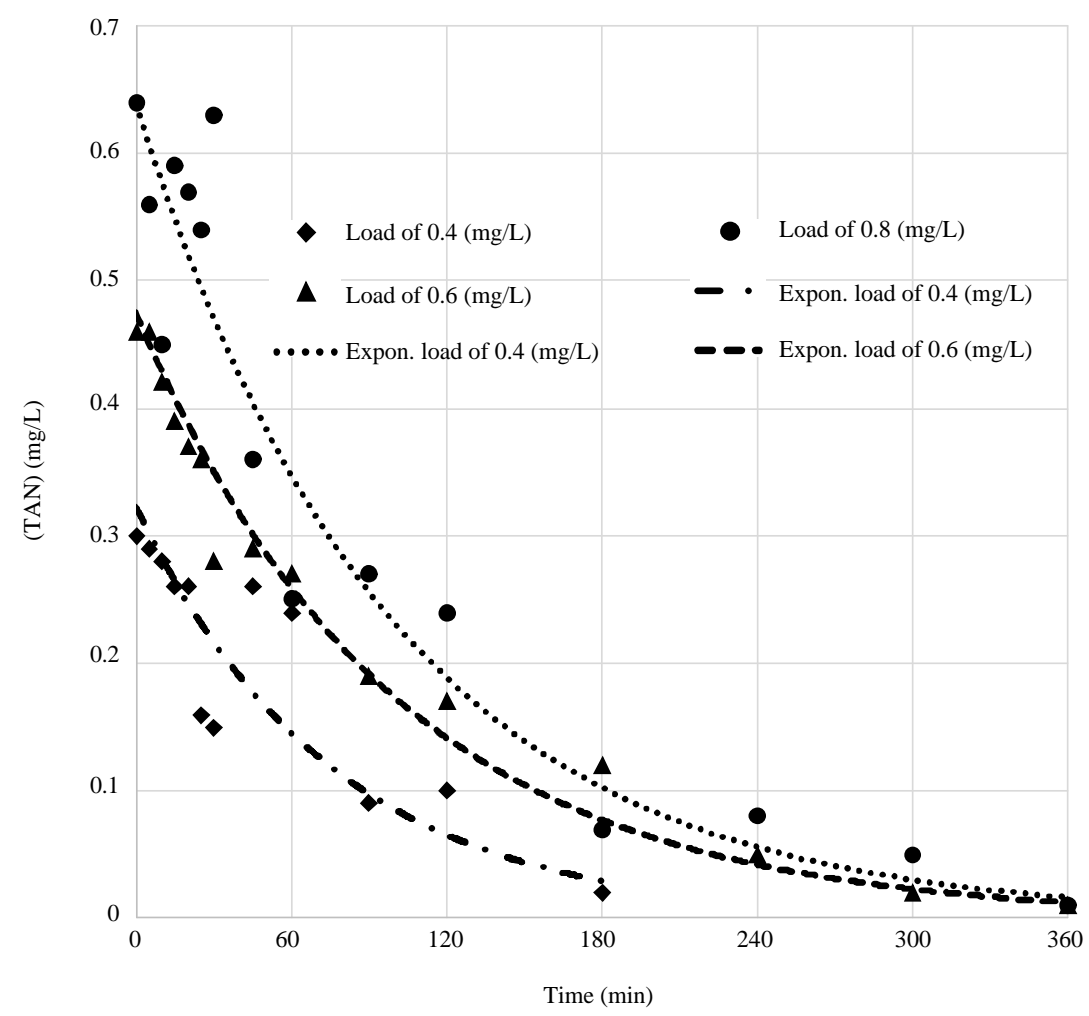

Fig. 1: Reaction kinetics of $0.4,0.6$ and $0.8 \mathrm{mg}$ TAN/L. These graphs contain the exponential graphs resulted from the data obtained from the experiments. The exponential model was chosen, since, it produced higher numbers of $\mathrm{R}^{2}$ which shown in Table 2

This was done to avoid the accumulation of TAN considering the processes that took place were on the condition of the first order kinetics.

The nitrification rate and removal efficiency could be influenced by control parameters. The rate of nitrification was improved by increasing the $\mathrm{pH}$ up to alkaline conditions resulting in a neutral $\mathrm{pH}$ in the biofilm (Flora et al., 1999). It was very influential in nitrifying biofilter operation because of the higher $\mathrm{pH}$ was more optimum for biofilter. $\mathrm{pH}$ that occurred in the water had a different scale with $\mathrm{pH}$ at the surface of biofilm as the water flew closer to the biofilm, the $\mathrm{pH}$ decreased.

This process happened in a TAN limitation condition where the amount of TAN entered the system could influence the nitrification process. This is the reason why different load could result in a different removal rate. TAN limitation happened because the experiment conducted was not in Dissolved Oxygen (DO) limitation condition as the DO concentration was in the range above $2 \mathrm{mg} / \mathrm{L}$ $(4,12-7,87 \mathrm{mg} / \mathrm{L})$ and the value of $\mathrm{gO}_{2} / \mathrm{g} \mathrm{NH}_{4}{ }^{+} \mathrm{N}$ was more than 5 (Zhang et al., 2014).
Indonesia's tropical climate created quite a warm temperature. The average TAN removal efficiencies of sponge-bed trickling filter were above $80 \%$. Based on the experiment conducted by Sajuni et al. (2010) on biological treatment system for removing ammonia in the fish tank, the removal efficiency achieved more than $93.5 \%$ when the temperature ranged between $31-32^{\circ} \mathrm{C}$ and decreased into around $80 \%$ when the temperature $28^{\circ} \mathrm{C}$. Biochemical process driven by bacteria accelerated when higher temperature occurred, consequently, it also, enhanced the nitrification rate (Chen et al., 2006).

Based on the ANOVA test, it could be known that significant differences occurred in the value of VTR $(p<0.05)$ with the largest average VTR occurred in the load of $0.8 \mathrm{mg}$ TAN/L day. No significant difference occurred in the removal efficiency $(p>0.05)$, so that, the decision-making continued using box plots.

Figure 2 (Top) a load of $0.6 \mathrm{mg}$ TAN/L day yielded an average of removal efficiency $>0.8 \mathrm{mg}$ TAN/L day but the minimum value of removal efficiency that occurred in $0.6 \mathrm{mg} \mathrm{TAN} / \mathrm{L}$ day was still lower than the minimum value at a load of $0.8 \mathrm{mg}$ TAN/L day. Figure 2 (Bottom) a load of $0.8 \mathrm{mg}$ TAN/L day resulted in mean and median which 

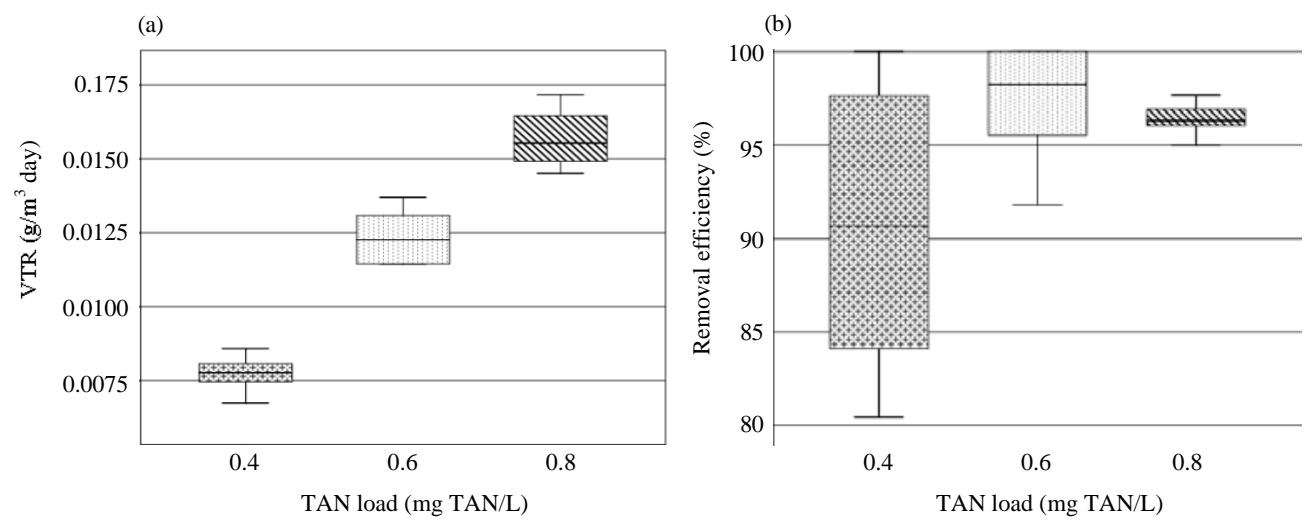

Fig. 2: a, b) (Top) box plot of VTR; (Bottom) box plot of removal efficiency

were greater than other load variations even though it had a longer box and with a lower VTR but this load was considered to create more optimum conditions in the operation of the sponge-bed trickling filter.

\section{CONCLUSION}

The tests using a sponge-bed trickling filter at a load of $0.4,0.6$ and $0.8 \mathrm{mg}$ TAN/L produced removal efficiency of $90.66 \pm 7.955 \%, 3.260 \% \pm 97.30$ and $96.41 \pm 0,880 \%$, respectively while the value of VTR produced were $0.0077 \pm 0.00060 \mathrm{~g} / \mathrm{m}^{2}$ day, $0.0124 \pm 0.00095 \mathrm{~g} / \mathrm{m}^{2}$ day and $0.0157 \pm 0.00104 \mathrm{~g} / \mathrm{m}^{2}$ day, respectively. The most optimum load on the operation of the sponge-bed trickling filter with removal efficiency values and most stable VTR happened to the load of $0.8 \mathrm{mg}$ TAN/L.

At loads $1 \mathrm{mg}$ TAN/L, sponge-bed trickling filter operates on a first-order kinetics. At a load of 0.4, 0.6 and $0.8 \mathrm{mg}$ TAN/L generated kinetic constant value by $7 \times 10^{-4} \mathrm{~m} /$ day, $7 \times 10^{-4} \mathrm{~m} /$ day and $9 \times 10^{-4} \mathrm{~m} /$ day, respectively and the TAN removal rate for each of $0.67 \mathrm{~g} / \mathrm{m}^{2}$ day, $0.46 \mathrm{~g} / \mathrm{m}^{2}$ day and $0.41 \mathrm{~g} / \mathrm{m}^{2}$ day, respectively.

\section{SUGGESTION}

The test should also be conducted on the load $1 \mathrm{mg}$ TAN/L to see the characteristics and kinetics of the nitrification process in progress. Further testing is needed by using the more complex wastewater characteristics such as the addition of the organic content or increased levels of TSS.

\section{SIGNIFICANCE STATEMENT}

The novelty of this study lies in the characteristics of wastewater and the type of trickling filter media with respect to previous studies using trickling filters with media sponges in domestic wastewater treatment (Zhang et al., 2014) and using LECA as trickling filter media for RAS. Research related to RAS on freshwater aquaculture wastewater treatment that is still uncommon in Indonesia is one of the drivers to determine the effect of sponges as trickling filter media in tropical climate conditions to set aside TAN.

\section{ACKNOWLEDGEMENT}

The researcher are indebted to Environmental Engineering Laboratory Universitas Indonesia for us operating and testing the reactor in the lab. The researcher are thankful for the financial support of Hibah Publikasi Internasional Terindeks Untuk Tugas Akhir Mahasiswa UI(PITTA UI)No. 2529/UN2.R3. 1/HKP.05.00/ 2018.

\section{REFERENCES}

Ahnen, M.V., L.F. Pedersen, P.B. Pedersen and J. Dalsgaard, 2015. Degradation of Urea, Ammonia and Nitrite in moving bed biofilters operated at different feed loadings. Aquacult. Eng., 69: 50-59.

Chen, S., J. Ling and J.P. Blancheton, 2006. Nitrification kinetics of biofilm as affected by water quality factors. Aquacult. Eng., 34: 179-197.

Eding, E.H., A. Kamstra, J.A.J. Verreth, E.A. Huisman and A. Klapwijk, 2006. Design and operation of nitrifying trickling filters in recirculating aquaculture: A review. Aquacul. Eng., 34: 234-260. 
Flora, E.M.C.V., M.T. Suidan, J.R.V. Flora and B.J. Kim, 1999. Speciation and chemical interactions in nitrifying bio?lms. I: Model development. J. Environ. Eng., 125: 871-877.

Harwanto, D., S.Y. Oh and J.Y. Jo, 2011. Comparison of the nitrification efficiencies of three biofilter media in a freshwater system. Fish. Aquat. Sci., 14: 363-369.

Losordo, T.M. and A.O. Hobbs, 2000. Using computer spreadsheets for water flow and biofilter sizing in recirculating aquaculture production systems. Aquacul. Eng., 23: 95-102.

Lyssenko, C. and F. Wheaton, 2006. Impact of rapid impulse operating disturbances on ammonia removal by trickling and submerged-upflow biofilters for intensive recirculating aquaculture. Aquacul Eng., 35 : 38-50.

Malone, R.F. and L.E. Beecher, 2000. Use of floating bead filters to recondition recirculating waters in warmwater aquaculture production systems. Aquacul. Eng., 22: 57-73.
Masser, M.P., J. Rakocy and T.M. Losordo, 1992. Recirculating aquaculture tank production systems: Management of recirculating systems. SRAC Publication No. 452, United States Department of Agriculture, Washington, D.C. USA. https:/cals. arizona.edu/azaqua/extension/Classroom/SRAC/45 4fs.pdf

Sajuni, N.R., A.L. Ahmad and V.M. Vadivelu, 2010. Effect of filter media characteristics, $\mathrm{pH}$ and temperature on the ammonia removal in the wastewater. J. Applied Sci., 10: 1146-1150.

Suantika, G., M.I. Pratiwi, M.L. Situmorang, Y.A. Djohan and $\mathrm{H}$. Muhammad et al., 2016. Ammonium removal by nitrifying bacteria biofilm on limestone and bioball substrate established in freshwater trickling biofilter. Poult. Fish. Wildl. Sci., 4: 157-163.

Zhang, S., Y. Wang, W. He, M. Wu and M. Xing et al., 2014. Impacts of temperature and nitrifying community on nitrification kinetics in a moving-bed biofilm reactor treating polluted raw water. Chem. Eng. J., 236: 242-250. 